\title{
DISPHANIA ANTHELMINTICA (AMARANTHACEAE), NEW TO THE NON- NATIVE FLORA OF ITALY, AND TAXONOMIC CONSIDERATIONS ON THE RELATED SPECIES
}

\author{
Duilio IAMONICO ${ }^{1}$
}

\begin{abstract}
Dysphania anthelmintica is recorded for the first time for Italy (Lazio region). Morphological and ecological characteristics of this plant and its invasive status, as compared with those of Dysphania ambrodioides and Chenopodium suffruticosum, are presented and discussed. Taxonomical notes are also provided.

Key words: Alien species, Ciampino, Chenopodium suffruticosum Willd., Dysphania R. Br., Dysphania ambrosioides (L.) Mosyakin \& Clemants, Lazio Region, Italy, Pavona.

Izvleček

Na ozemlju Italije (območje Lazio) smo prvič zabeležili vrsto Dysphania anthelmintica. Obravnavali smo morfološke in ekološke značilnosti te vrste in njen invazivni status v primerjavi z vrstama Dysphania ambrodioides in Chenopodium suffruticosum. Predstavili smo tudi taksonomske opombe.

Ključne besede: tujerodna vrsta, Ciampino, Chenopodium suffruticosum Willd., Dysphania R. Br., Dysphania ambrosioides (L.) Mosyakin \& Clemants, območje Lazio, Italija, Pavona.
\end{abstract}

\section{INTRODUCTION}

The generic name Dysphania $\mathrm{R}$. Br. has been traditionally applied to 7-10 species endemic to Australia (Aellen 1930a, Scott 1978, Wilson 1983). Placement and rank of this taxon have ranged from a single genus of a family Dysphaniaceae (Pax \& Hoffmann 1934), over a genus included in Illecebraceae or Caryophyllaceae, to a mere section of Chenopodium L. in the Chenopodiaceae (Aellen 1930a, Aellen 1930b). Recent phylogenetic studies (Kadereit et al. 2003, Kadereit et al. 2005) have confirmed the position of Dysphania within Chenopodiaceae and indicated its close ralationship with Chenopodium species characterized by the presence of multicellular glandular hairs. Thus, they supported the proposal by Mosyakin \& Clemants $(2002,2008)$ to transfer the glandular species to Dysphania R. Br.

The genus Dysphania was accepted subsequently in the Flora of North America (Clem- ants \& Mosyakin 2003) and the Flora of China (Zhu Gelin et al. 2003) as well as by some European botanists (e.g., Celesti-Grapow et al. 2009a, Celesti-Grapow et al. 2009b, Iamonico 2009, Celesti-Grapow et al. 2010).

At present, the genus Dysphania includes about 45 species (Western Australian Herbarium 1998-2009, Mosyakin \& Clemants 2002, Verloove \& Lambinon 2006) Mosyakin \& Clemants 2008, and is included by APG III (2009) in the widely circumscribed Amaranthaceae (incl. Chenopodiaceae). Most of them are native to the Americas (18 species) and to Australia (20 species), while the remaining ones to Africa, Asia and Europe (see IPNI 2008). For Europe 9 species (sub Chenopodium spp.) are reported (Brenan 1964, Jalas \& Souminen 1980, Greuter et al. 1984, Akeroyd 1993, DAISIE 2008), mostly distributed in central and southern Europe.

Dysphania differs from Chenopodium in having multicellular glandular hairs (especially on the

${ }^{1}$ Via dei Colli Albani 170, 00179-Roma, Italy, e-mail: duilio76@yahoo.it 
stem) and a strong aromatic odour [some species (e. g. D. aristata (L.) Mosyakin \& Clemants) have the stem slightly glandular, not aromatic and the terminal branches of the inflorescences bristletipped]; Chenopodium has the stem glabrous or farinose (never glandular), not aromatic (sometimes malodorous) and branches never bristletipped.

Chenopodium anthelminticum L. also belongs to the group of taxa now included in Dysphania, as D. anthelmintica (L.) Mosyakin \& Clemants. According to the infrageneric classification proposed by Mosyakin \& Clemants $(2002,2008)$, the species is included in the Sect. Adenois (Moq.) Mosyakin \& Clemants and it is closely related with the polymorphic D. ambrosioides (L.) Mosyakin \& Clemants. Other authors (e.g. Aellen 1960-1961, Pignatti 1982) also included in this aggregate the species $C$. suffruticosum Willd.

D. anthelmintica is probably native to the Atlantic and Gulf coast of north America (Clemants and Mosyakin 2003), so it is an alien species for Italy and Europe.

In this paper D. anthelmintica (L.) Mosyakin \& Clemants is reported for the first time for Italy (Lazio region) its invasive status, as well as taxonomical, morphological and ecological notes are provided. A comparison with the related species D. ambrosioides is also given. Moreover, the identity of another, putatively closely related species (C. suffruticosum), is discussed and clarified.

\section{MATERIALS AND METHODS}

Plants, later determined as D. anthelmintica, were collected in RO and in the personal Herbarium of the author (Herb. Iamonico).

Macromorphologial data were obtained both from living plants or from exsiccata kept in B!, FTG! RO!, FI!, LINN!, S! and in the personal Herbarium of the author (Herb. Iamonico). The following characters were measured/observed: plant life form (annual or perennial), habitus (herbaceous or suffruticose), leaves [length and width of the blades, ratio length/width (shape of the blade), margins (entire, dentate or serrate)], inflorescence [structure (single or compound panicle), length of the glomerules, presence and length of the subtending leaves].

Taxonomical considerations are based on an extensive analysis of the literature, and on the examination of the herbarium specimens (some are available on the web: Fairchild Tropical Botanic Garden 2007, Röpert 2008, Linnean Society Collections Online 2009).

The protologue by Linnaeus (1753) and the descriptions by Clemants \& Mosyakin (2003) were used to identify the species. The plants were also examined by Prof. S. L. Mosyakin (National Academy of Sciences of Ukraine) to confirm my identification.

The evalutation of the invasive status follows Pyšek et al. (2004).

\section{RESULTS AND DISCUSSION}

\section{TAXonomical notes}

Dysphania anthelmintica was first described (sub $C$. anthelminticum) from "Pensylvania" in 1753 (Linnaeus 1753) as "CHENOPODIUM ... racemis aphyllis". Moquin-Tandon (1840) applied the name Ambrina anthelmintica Spach. and reported "Affini A. ambrosioidi, sed perennis et spicis non foliosis...". De Candolle (1849) indicated $C$. anthelminticum as " $C$. Ambrosioidi affine, sed perenne... et spicis aphyllis". Gray \& Sullivant (1856) proposed the new combination C. ambrosioides var. anthelminticum (L.) Gray, and reported that it differs from the typical variety in having the "spikes... mostly leafless". Robinson \& Fernald (1908) accepted the choice by Gray (1956). Coste (1908) treated C. anthelminticum at specific rank with "... glomérules ... plus ou moins feuillée ..." [“... glomerules ... more or less leafy ..."]. Two years later, Rouy (1910) reported C. anthelminticum as variety of $C$. ambrosioides [according to Gray (1856)] indicating “... grappes bien moin feuillées ou presque nues ..." [“... glomerules with few bracts or leafless ..."]. Aellen (1929) proposed the combination C. ambrosioides var. anthelminticum (L.) Aellen, but this name is a later homonym of C. ambrosioides var. anthelminticum (L.) Gray, so it is illegittimate under art. 53.1 of ICNB (McNeill et al., 2006). Subsequently, Fournier (1946) quoted $C$. anthelminticum in a note under the description of $C$. ambrosiodes and reported "... bractées trés petit cachées sous les verticilles ..." [“... bracts very small hidden by the glomerules ..."]. Guinochet \& Vilmorin (1973) included C. anthelminticum in the synonymy of $C$. ambrosioides. The comprehensive European floras (Brenan 1964, Jalas \& Souminen 1980, Greuter et al. 1984, Akeroyd 1993) have not listed $D$. anthelmintica, only $C$. ambrosioides with "... Infiorescence ... bracteate ...", 
and included the name $C$. anthelminticum auct. non L. in synonymy. More recently, Mosyakin \& Clemants (2002) proposed the new combination Dysphania anthelminthica (L.) Mosyakin \& Clemants, accepting its specific rank, and later, in the determination key of the genus Dysphania in the Flora of North America (Clemants \& Mosyakin 2003), indicated its morphological affinity with D. ambrosioides (L.) Mosyakin \& Clemants, from which it differs in having the "Inflorescences leafless (glomerules without subtending leaves throughout inflorescence, or subtending leaves very small, shorter than glomerules)".

Another morphologically similar species is Chenopodium suffuricosum Willd., first described from "Pensylvania, Mexico" in 1809 (Willdenow 1809); the author also reported "Valde simile preacedenti [C. ambrosioides], sed folia magis vel potuis profundius dentata, venis subtus ramosioribus; racemi basi quandoque subcompositi; caulis suffruticosus ...". Moreover, Willdenow (1809) indicated "Accepi sub nomine Chenopodii anthelmitici, sed huic racemi aphylli ... quod in nostro nunquam observatur ...". The name C. suffurticosum was often not included in the works (e.g. Coste 1908, Rouy 1910, Fournier 1946, Akeroyd 1993), sometimes considered as an independent species (e.g. Aellen 19601961, Pignatti 1982), but usually considered as a synonym of $C$. ambrosioides (e.g. Moquin-Tandon 1840, Uotila 1990, Clemants \& Mosyakin 2003), sometimes as an ambiguous synonym of (e.g. De Candolle 1849, Greuter et al., 1984).

The comparison of the original descriptions of C. ambrosioides (Linnaeus 1753), C. anthelminticum (Linnaeus 1753) and C. suffruticosum (Willdenow 1809) shows that the first one is most similar to C. suffruticosum both in shape and margins of the leaves ("Foliis lanceolatis dentatis" vs. "Foliis lanceolatis remote dentatis") and in inflorescence type ("racemis foliatis simplicibus" vs. "racemis ... simplicibus foliatis ... subcompositi"). The morphological differentiation based on these characters is rather weak, but they differ in life form, C. ambrosioides being annual and C. suffruticosum perennial (Willdenow 1809: "caule suffruticoso"). Chenopodium anthelminticum differs from both other taxa in having the inflorescence leafless (Linnaeus 1753, Willdenow 1809).

After examining several specimens, including the type specimens, as well as observing the plants in nature, the following conclusions can be drawn:
1. C. ambrosioides is usually an annual herb, sometimes biennal or perennial (in the latter case the plants show a shrub-habitus). The margins of the leaves are usually dentate or serrate (sometimes entire). The inflorescence is very variable, especially in general structure (from single or few spikes to compound panicle); leaves subtending the glomerule are always present and much longer than these;

2. Plants previously determined as C. suffruticosum are always perennial. The margins of the leaves are dentate. The inflorescence is usually compound (rarely simple) and always leafy;

3. C. anthelminticum is a perennial shrub [Mosyakin \& Clemants (2003) report this species as annual for North America]. The margins of the leaves are usually dentate (sometimes entire or laciniate). The inflorescence is always compound, with several spikes (in plants from Italy, I counted over 100 spikes per individual!); leaves subtending the glomerule are absent or, when present, very small, shorter or subequal to the glomerules.

Based on these observations, the variability of C. suffruticosum is fully included in that of C. ambrosioides, so the two names can be considered synonyms (the latter name having priority). Regarding C. anthelminticum, I suggest its treatment at the specfic rank thus following Mosyakin \& Clemants $(2002,2003)$.

\section{OGGURRENCE IN ITALY}

In the former Italian floras only Pignatti (1982) indicated $D$. anthelmintica (sub C. anthelminticum) under the C. ambrosioides group and reported: "Simile è Ch. anthelminticum L., con inflor. afilla: largam. coltiv. nel Nordamer." ["Ch. anthelminticum is a similar species, with inflorescence leafless: widely cultivated in northern America."]; the author also pointed out the confusion with C. ambrosioides and C. suffruticosum.

The specimens collected in Italy and referred to $D$. anthelmintica are different and cannot be confused with those identified as D. ambrosioides (see discussion above). The main diagnostic characters are summarized in Table 1. A detailed description of $D$. anthelmintica follows the table (it is based on the characteristic of the specimens studied). 
Table 1: Diagnostic features of Dysphania anthelmintica and Dysphania ambrosioides.

Tabela 1: Značilni znaki za vrsti Dysphania anthelmintica in Dysphania ambrosioides.

\begin{tabular}{|c|c|}
\hline Dysphania anthelmintica & Dysphania ambrosioides \\
\hline Plants perennial (shrub) & Plants usually annual (herb) \\
\hline $\begin{array}{l}\text { Leaves with margin entire, dentate or } \\
\text { laciniate }\end{array}$ & $\begin{array}{l}\text { Leaves with margin dentate } \\
\text { (usually with widely spaced teeth) }\end{array}$ \\
\hline $\begin{array}{l}\text { Glomerules without subtending leaves, } \\
\text { or with subtending leaves very small (bracts), } \\
\text { shorter or subequal glomerules }\end{array}$ & $\begin{array}{c}\text { Glomerules always with subtending leaves } \\
\text { longer than glomerules }\end{array}$ \\
\hline Seeds often vertical $(0.5-0.9 \times 0.7-1 \mathrm{~mm})$ & Seeds usually horizontal $(0.5-0.9 \times 0.4-0.5)$ \\
\hline
\end{tabular}

Dysphania anthelmintica (L.) Mosyakin \& Clemants, Ukrayins'k Bot. Zhurn., n.s. 59: 382 (2002) (Figg. 1-2)

Bas.: Chenopodium anthelminthicum L., Sp. Pl. 1: 220 (1753)

= Chenopodium ambrosioides L. var. anthelminticum
(L.) A. Gray, Manual (Gray), ed. 2: 364 (1856)

= Chenopodium suffruticosum Willd., Enum. Pl. [Willdenow] 1: 290 (1809)

= Chenopodium ambrosioides $\mathrm{L}$. var. suffruticosum (Willd.) Aellen, Repert. Spec. Nov. Regni Veg. 26: 35 (1929)



Figure 1: Dysphania anthelmintica (L.) Mosyakin \& Clemants from Ciampino (Province of Rome, central Italy), with its inflorescence magnified (A). Photo by D. Iamonico (14. 12. 2008).

Slika 1: Dysphania anthelmintica (L.) Mosyakin \& Clemants iz mesta Ciampino (provinca Rim, srednja Italija), povečano socvetje (A). Foto: D. Iamonico (14. 12. 2008). 
Shrub up to $80-100 \mathrm{~cm}$ that covers an area up to $1 \mathrm{~m}^{2}$. Stem branched, usually glandularpubescent, green to reddish. Proximal leaves petiolate, with blade ovate to lanceolate (1.0 $3.0 \times 5.0-7.0 \mathrm{~cm})$, margins dentate, base cuneate and apex acute; distal leaves sessile, smaller (up to $1.0 \times 4.0 \mathrm{~cm}$ ). Flowers are grouped in glomerules globose (diameter of the glomerules 1.5-3.0 $\mathrm{mm})$, arranged in several terminal and lateral spikes; bracts absent or, when present, leaflike, the glomerules very small, shorter or subequal; flowers with 5 tepals, connate to about $1 / 2$ of their length, ovate with apex obtuse, glabrous; stamens 5; stigmas 3. Fruit ovoid (1.0-1.5 mm), with pericarp smooth, glandular; seeds vertical (sometimes horizontal), ovoid $(0.5-0.9 \times 0.7-1.0 \mathrm{~mm})$, brown, coat smooth.

Clemants \& Mosyakin (2003) described D. anthelmintica as an annual plant, while the specimens collected by the author are perennial shrubs.

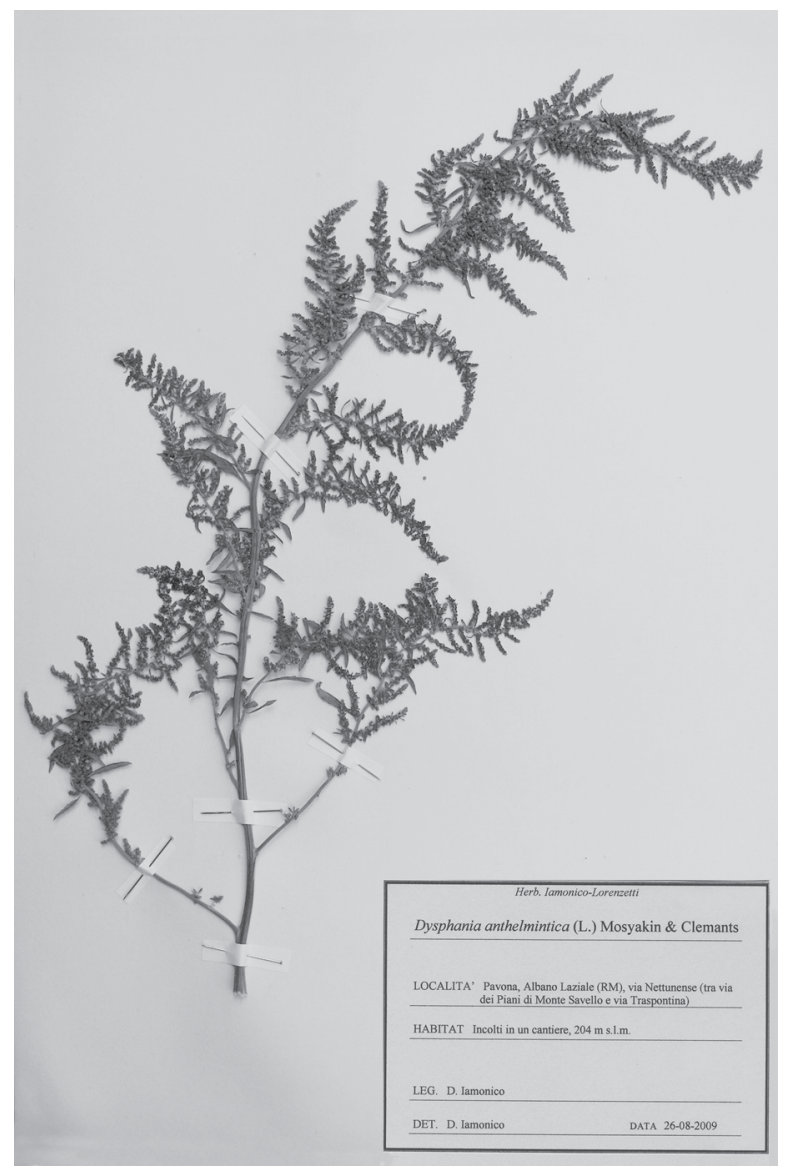

Figure 2: Specimen of D. anthelmintica. Photo by D. Iamonico (14. 12. 2008).

Slika 2: Primerek vrste D. anthelmintica. Foto: D. Iamonico (14. 12. 2008).
For the being time, we explain this character as morphological variability. S. Mosyakin (in verbis) confirms my determination in spite of this consideration.

According to Pyšek et al. (2004), this species can be considered naturalized in Italy.

In the Lazio region this species grows on arid fallows, embankments and roadsides (Fig. 1); it can be considered a thermophyte, xerophyte and heliophyte (pers. obs.). The flowering period observed is from August to October.

Further investigations are needed to verify the presence of D. anthelminatica in other Italian and European regions. Based on its ecology, we can expect to find this species mainly in disturbed areas (especially arid places e.g. roadsides, railways or fallow fields) of central and southern $\mathrm{Eu}-$ ropean countries.

\section{ACKNOWLEDGEMENTS}

Thanks are due to the Director and Curator of the Herbaria RO and FI for their support in my visit. I am also grateful to Prof. S.L. Mosyakin (National Academy of Sciences of Ukraine) for help in identification of $D$. anthelmintica and to Prof. C. Jarvis and Dr. B. Sherwood (The Linnean Society of London, London, UK) for permission to use and cite the on-line images of Linnaeus's specimens.

\section{REFERENCES}

Aellen, P. 1929: Repertorium Specierum Novarum Regni Vegetabilis, 26: 35. Verlag Von Gebrüder Borntraeger, Berlin.

Aellen, P. 1930a: Die systematische Stellung und Gliederung der R. Brownschen Gattung Dysphania. Bot. Jahrb. Syst. 63: 483-490.

Aellen, P. 1930b: Eine neue Sektion der Gattung Chenopodium (Sect. Tetrasepala). Bot. Jahrb. Syst. 63: 490-492.

Aellen, P. L. 1960-61. Chenopodium L. In: Hegi, G. (ed.): Illustrierte Flora von Mitteleuropa 3(2). Carl Hanser Verlag, München, pp. 569-659.

Akeroyd, J. 1993: Chenopodium L. In: Tutin, T. G., Burges, N. A., Chater, A. O., Edmondson, J. R., Heywood, V. H., Moore, D. M., Valentine, D. H., Walters, S. M. \& Webb, D. A. (eds.): Flora Europaea (second edition), 1. Cambridge University Press, Cambridge, pp. 111-114. 
APG III 2009: An update of the Angiosperm Phylogeny Group classification for the orders and families of flowering plants: APG III. Bot. J. Linn. Soc., 161: 105-121.

Brenan, J. 1964: Chenopodium L. In: Tutin, T. G., Heywood, V. H., Burges, N. A., Moore, D. M., Valentine, D. H., Walters, S. M. \& Webb, D. A. (eds.), Flora Europaea, 1. Cambridge University Press, Cambridge, pp. 92-25.

Celesti-Grapow, L., Alessandrini, A., Arrigoni, P. V., Banfi, E., Bernardo, L., Bovio, M., Brundu, G., Cagiotti, M. R., Camarda, I., Carli, E., Conti, F., Fascetti, S., Galasso, G., Gubellini, L., La Valva, V., Lucchese, F., Marchiori, S., Mazzola, P., Peccenini, S., Poldini, L., Pretto, F., Prosser, F., Siniscalco, C., Villani, M. C., Viegi, L., Wilhalm, T. \& Blasi, C. 2009a: Inventory of the non-native flora of Italy. Plant biosystem 143 (2): 386-430.

Celesti-Grapow, L., Pretto, F., Carli, E. \& Blasi, C. (eds.) 2009b: Non-native flora of Italy. Plant invasion in Italy - an overview. Palombi \& Partner, Roma, CD-ROM.

Celesti-Grapow, L., Pretto, F., Carli, E. \& Blasi, C. (eds.) 2010: Flora vascolare alloctona e invasiva delle regioni d'Italia. Casa Editrice Università La Sapienza, Roma, 208 pp.

Clemants, S. E. \& Mosyakin, S. L. 2003: Dysphania R. Br. In: Flora of North America Editorial Committee (eds.), Flora of North America north of Mexico, 4. Oxford University Press, New York \& Oxford, pp. 267-299.

Coste, H. 1908: Flore descriptive et illustrée de la France de la Corse et des contrées limitrophes. Librarie des Sciences Naturelles Paul Klincksieck, Paris. 807 pp.

DAISIE 2008: European Invasive Alien Species Gateway. Dysphania R. Br. http://www.europealiens.org/ (last accessed 20 July 2010).

De Candolle, A. 1849: Prodromus systematis naturalis regni vegetabilis 10 (3). Victoris Masson, Parisiis, 469 pp.

Fairchild Tropical Botanic Garden 2007: Fairchild Virtual Hebarium Web Portal. http://www.virtualherbarium.org/vhportal.html (last accessed 20 July 2010).

Fournier, P. 1946: Les Quatre Flores de France. Paul Lechevaler, Paris. 1106 pp.

Gray, A. \& Sullivant, W. S., 1856: A Manual of the Botany of the Northern United States, Ed. 2. 739 pp.

Greuter, W., Burdet, H. \& Long, G. (eds.) 1984 : Med-checklist. Pteridophyta, Gymnospermae,
Dicotyledones (Acanthaceae-Cneoraceae), 1. Conservatoire et jardins botaniques de la Ville de Genève, Geneve, 414 pp.

Guinochet, M. \& Vilmorin, R. 1973: Flore de France 1. C.N.R.S, Paris. 366 pp.

Iamonico, D. 2009: Notula 1621. Dysphania R. Br. (Amaranthaceae). Notulae nomenclaturali alla Checklist della flora italiana: 7. Inform. Bot. Ital. 41 (2): 358.

IPNI 2008: The International Plant Names Index. http://www.ipni.org (accessed 20 July 2010).

Jalas, J. \& Suominen, J. 1980: Atlas florae Europeae. Distribution of Vascular Plants in Europe, 5. Helsinki University Printing House, Helsinki, 119 pp.

Kadereit, G., Borsch, T., Weising, K. \& Freitag, H. 2003: Phylogeny of Amaranthaceae and Chenopodiaceae and the evolution of C4-photosynthesis. Intl. J. Pl. Sci. 164: 959-986.

Kadereit, G., Gotzek, D., Jacobs, S. \& Freitag, H. 2005: Origin and age of Australian Chenopodiaceae. Organisms, Diversity \& Evol. 5: 59-80.

Linnaeus, C. 1753: Species Plantarum, 1. Salvius, Stockholm, $560 \mathrm{pp}$.

Linnean Society Collections Online 2009: The Linnean collections. http:// www.linnean-online.org/ (last accessed July 2010).

McNeill, J., Barrie, F. R., Burdet, H. M., Demoulin, V., Hawksworth, D. L., Marhold, K., Nicolson, D. H., Prado, J., Silva, P. C., Skog, J. E., Wiersema, J. H. \& Turland, N. J. (eds) 2006: International Code of Botanical Nomenclature (Vienna Code) Adopted by the Seventeenth International Botanical Congress Vienna, Austria, July 2005. A.R.G. Gaertner Verlag, Ruggell, Liechtenstein.

Moquin-Tandon, A. 1840: Chenopodearum monographica enumeratio. Apud P.-J. Loss, Parisiis, 182 pp.

Mosyakin, S. L. \& Clemants, S. E. 2002: New nomenclatural combinations in Dysphania R. Br. (Chenopodiaceae): taxa occurring in North America. Ukrayins'k. Bot. Zhurn. (Ukr. Bot. J.) 59: 380-385.

Mosyakin, S. L. \& Clemants, S. E. 2008: Further transfer of glandular-pubescent species from Chenopodium subg. Ambrosia to Dysphania (Chenopodiaceae). J. Bot. Res. Inst. Texas 2 (1): 425-431.

Pax, F. A. \& Hoffmann, K. 1934: Dysphaniaceae. In: Engler, A. \& Harms, H. (eds.), Die natürlichen Pflanzenfamilien, 16c. Duncker \& Hunbolt, Berlin, pp. 272-274. 
Pignatti, S. 1982: Flora d'Italia, 1. Edagricole, Bologna, 790 pp.

Pyšek, P., Richardson, D. M., Rejemánek, M., Webster, G. L., Williamson, M. \& Kischner, J. 2004: Alien plants in checklist and floras: towards better communication between taxonomist and ecologist. Taxon 53 (1): 131-143.

Robinson, B. L. \& Fernald, M. L. 1908: A handbook of the flowering plants and ferns of the central and northeastern United States and adjacent Canada. American Book Company, New York, Cincinnati, Chicago, 926 pp.

Röpert, D. (ed.) 2008: Digital specimens' images at the Herbarium Berlinense. http://ww2.bgbm.org/herbarium/default.cfm (last accessed 20 July 2010).

Rouy, G. 1910: Flore de France ou description des plantes qui croissent spontanément en France, en Corse et en Alsace-Lorraine 12. Société des Sciences Naturelles de la Charente-Inférieure, Paris, 505 pp.

Scott, A. J. 1978: A review of the classification of Chenopodium L. and related genera (Chenopodiaceae). Bot. Jahrb. Syst. 100: 205-220.
Verloove, F. \& Lambinon, J. 2006: The non-native vascular flora of Belgium: a new nothospecies and three new combinations. Syst. Geogr. Pl. 76: 217-220.

Western Australian Herbarium 1998-2009: FloraBase-The Western Australian Flora, Department of Environment and Conservation. http://www.florabase.dec.wa.gov.au/ (last accessed 20 July 2010).

Willdenow, C. L. 1809: Enumeratio Plantarum Horti Regii Botanici Berolinensis. Taberna Libraria Scholae Realis, Berolini. 1099 pp.

Wilson, P. G. 1983: A taxonomic revision of the tribe Chenopodieae (Chenopodiaceae) in Australia. Nuytsia 4: 135-262.

Zhu Gelin, Mosyakin, S. L. \& Clemants, S. E. 2003: Dysphania R. Br. In: Wu, Z. Y., Raven, P. H. \& Hong, D. Y. (eds.), Flora of China, 5. Science Press, Beijng and Missouri Botanical Garden Press, St. Louis, pp. 376-378.

Received 29. 7. 2010

Revision received 15. 10. 2010 Accepted 18. 10. 2010 


\section{APPENDIX}

Specimina visa selecta.

Dysphania anthelmintica (L.) Mosyakin \& Clemants - P. Kalm, sine die (LINN 313.15) (sub Chenopodium anthelminticum L.). - Italy: Lazio, Pavona (Prov. Roma), via Nettunense (tra via dei Piani di Monte Savello e via Traspontina), cantiere, 204 m a.s.l., 06-09-2008, D. Iamonico (RO, Herb. Iamonico); Lazio, Ciampino (Prov. Roma), località Casale dei Francesi, incolto nei pressi del Cimitero comunale, $163 \mathrm{~m}$ a.s.l., 14-12-2008, D. Iamonico (RO, Herb. Iamonico); Lazio, Pavona, Albano Laziale (Prov. Roma), via Nettunense (tra via dei Piani di Monte Savello e via Traspontina), incolto in un cantiere, $204 \mathrm{~m}$ a.s.l., 26-08-2009, D. Iamonico (RO, Herb. Iamonico); Lazio, Pavona, Albano Laziale (Prov. Roma), Via Nettunense (all'altezza di via dei Piani di Monte San Savello), margine stradale, $200 \mathrm{~m}$ a.s.l., 12-09-2009, D. Iamonico (RO, Herb. Iamonico); Lazio, Ciampino (Prov. Roma), località Casale dei Francesi, incolto nei pressi del Cimitero comunale, $163 \mathrm{~m}$ a.s.l., 27-12-2009, D. Iamonico (RO, Herb. Iamonico);

Dysphania ambrosioides (L.) Mosyakin \& Clemants - C. Linnaeus, sine die (LINN 313.13) (sub Chenopodium ambrosioides L.). Sine collectore, sine die (sub Chenopodium ambrosioides L.) (S). - Costa Rica: Puntarenas, San Gerardo de Limon, 11-042002, A.L. Frances (FTG). - Equador: XIX sec., leg. et det. A.J.A. Bonpland \& F.W.H.A. von Humboldt (sub C. suffruticosum), rev. P. Aellen (10-031930) (B). - Italy: Campania, Regno di Napoli, raccolto alla Cava, XIX sec., sine collectore, det. F. Cortesi (RO); Emilia-Romagna, dintorni di Modena, 28-08-1894, A. Mori (RO); Calabria, Valle del Lao, Laino Borgo, margine di una via, 16-07-1892, sine collectore (RO); Marche, Porta Civitanova, sine collectore (RO); Abruzzo, Pescara, 04-10-1955, B. Anzalone (RO); Liguria, Genova, nell'alveo del fiume, al lungobisogno Istria, 15 Oct 1955, G. Lusina (RO); Lazio, Gaeta, 07-1970, B. Anzalone (RO); Lazio, Roma, Ponte Via Olimpia, rive del Tevere (riva dest.), 08-1977, B. Anzalone (RO). - Panama: 11-01-1971, J.F. Morton (FTG); 11-01-1976, f.F. Morton (FTG). Perù: Cuzco, 3004-1977, A. Gentr (FTG). - Portugal: Azoren, Sao Miguel, zw. Ribeira Grande u. Lago a do Fogo, 24-10-1998, E. Royl (B). - USA: Florida, Collier, 15-04-1949, R.B. Ledin (FTG); Florida, Dade, 0311-1912, f.K. Small (FTG); Florida, Dade, 17-061978, D.S. Correll (FTG); Florida, Martin, 12-121999, S.W. Woodmansee (FTG); Florida, Lee, 0207-1931, W.M. Buswell (FTG); South California, 17-07-1971, f.F. Morton (FTG). 